\title{
Pendampingan Masyarakat Dusun Lidah Wetan dalam Pelestarian Budaya Literasi dengan Pembuatan Perpustakaan Mini dan Taman Baca di Surabaya
}

\author{
Susi Ratnawati, Slamet Erianto \\ Universitas Bhayangkara Surabaya \\ susiratna11@gmail.com, slameterianto05@gmail.com
}

\begin{abstract}
:
Lidah Wetan Hamlet, Lakar Santri Subdistrict, Surabaya, is one of the villages in Surabaya that has a very dense population. In this digital era, children and young people are less aware of the need to read. In the tongue, teenagers are not so concerned with learning. Bhayangkara University in Surabaya held a Community Service program which took place in the Lidah Wetan Hamlet, Lakarsantri District, Surabaya City. With the theme "Preserving Literacy Culture". The program is inseparable from the vision and mission of local village officials. With the mini library created by Community Service Team, Bhayangkara University is expected to increase the enthusiasm and interest in reading in the surrounding community. This mini library provides a variety of books ranging from children's story books, learning books to read, learning books to write, learning books to draw, school materials, to religious nuances books and other books (food recipes, fiction stories, etc.). Some programs are directed at encouraging children's potential in reading culture and fostering youthful enthusiasm in organizing. Nowadays many young people are trying to challenge Karangtaruna. Several agendas are designed to solve these problems.
\end{abstract}

Keyword: preserving, culture, literacy, mini library

\section{Pendahuluan}

Budaya literasi di Indonesia belum dianggap sebagai suatu hal yang penting. Minat baca bangsa sangat mengkhawatirkan, padahal dari membaca, kemampuan berbahasa lainnya seperti menulis dan berbicara akan meningkat. Membaca adalah jendela dunia yang membuat manusia dekat dengan karya sastra, buku, karakter bangsa, dan peradaban.

Literasi Informasi sebagai kemampuan untuk mengetaui kebutuan informasi untuk memecahkan masalah, mengembangkan gagasan, mengajukan pertanyaan penting menggunakan berbagai strategi pengumpulan informasi, menetapkan informasi yang cocok relevan dan otentik secara efektif menggunakan informasi 
tersebut untuk isu atau masalah yang dihadapi agar masyarakat melek pada sebuah informasi. Untuk meredam pengaruh-pengaruh budaya global yang kuat diperlukan literasi dan kesadaran masyarakat akan pentingnya pelestarian budaya lokal. Generasi muda harus dapat mengembangkan kemampuan diri dalam menghadapi era global, tetapi jangan sampai terbawa arus budaya global yang tidak sesuai dengan budaya sendiri.

Berbagai laporan dari lembaga kompeten, baik nasional maupun internasional, baik pemerintah maupun institusi non pemerintah (Non Governmental Organization), menunjukkan bahwa indeks minat baca dan tingkat literasi masyarakat Indonesia masih sangat rendah dan memprihatinkan.

UNESCO (United Nations Educational, Scientific and Cultural Organization) misalnya, pernah merilis data yang menunjukkan bahwa minat baca masyarakat Indonesia baru 0,001 persen.(Khoiruddin, Taulabi, \& Imron, 2016) Itu artinya dari seribu orang, hanya ada satu yang memiliki minat baca. Ingat, ini hanya "minat baca". Belum tentu ia suka membaca. Organization for Economic Cooperation and Development (OECD) juga pernah melansir hasil survei yang menunjukkan, kemampuan membaca, berhitung, dan pengetahuan sains anak-anak Indonesia masih di bawah negara-negara tetangga seperti Singapura, Malaysia, Vietnam dan Thailand, dan sejajar dengan negara-negara miskin di Afrika.

Bahkan dari 40 negara yang dites, Indonesia berada di posisi paling buntut. Menurut World Economic Forum, tingkat literasi dasar yang perlu dikuasai oleh orang dewasa meliputi kemampuan baca-tulis, literasi numerasi atau berhitung, literasi finansial (keuangan), literasi sains, literasi budaya dan kewarganegaraan, serta literasi informasi teknologi dan komunikasi atau digital. Rendahnya reading literacy bangsa kita menyebabkan Sumber Daya Manusia kita tidak kompetitif karena kurangnya penguasaan ilmu pengetahuan dan teknologi, sebagai akibat lemahnya minat dan kemampuan membaca dan menulis.(Teguh, 2013)

Pada saat ini sesungguhnya para siswa dihadapkan pada pada persoalan bagaimana mengatasi keterbatasan waktu dan dapat membaca dalam waktu yang 
relatif singkat tetapi dapat memperoleh informasi yang sebanyak-banyaknya (Arum Nisma Wulanjani \& Candradewi Wahyu Anggraeni, 2019). Bagaimana dapat melakukan kegiatan membaca secara efektif tanpa membuang-buang waktu. Selaras dengan pernyataan tersebut, terlihat bahwa kemampuan literasi membaca sangatlah dibutuhkan para siswa seiring dengan pesatnya perkembangan informasi dan teknologi di masa sekarang ini. Hanggi (2016) menyatakan bahwa literasi membaca dapat menjadi sarana bagi siswa dalam mengenal, memahami, dan menerapkan ilmu yang didapatkan di sekolah. Literasi dasar, termasuk lilterasi membaca, sudah selayaknya perlu ditanamkan sejak pendidikan dasar (Arum Nisma Wulanjani \& Candradewi Wahyu Anggraeni, 2019). Hal tersebut diperlukan supaya para siswa dapat meningkatkan kemampuannya dalam upaya mengakses informasi ataupun ilmu pengetahuan. Literasi akan mengantarkan para siswa untuk memahami suatu pesan. Pentingnya literasi juga disampaikan oleh Kemendikbud (2016) bahwa budaya literasi yang tertanam dalam diri peserta didik mempengaruhi tingkat keberhasilan dan kemampuan peserta didik untuk memahami informasi secara analitiss, kritis, dan reflektif. Pemerintah juga telah mencanangkan program Gerakan Literasi Bangsa (GLB) yang bertujuan untuk menumbuhkan budi pekerti anak melalui budaya literasi (membaca dan menulis).

Memang ada sejumlah anak Indonesia yang beberapa kali menjuarai olimpiade sains dan matematika tingkat internasional, sebuah prestasi gemilang yang perlu diapresiasi. Tetapi itu hanya sekelumit contoh dari anak-anak tangguh dan berprestasi saja, tidak merepresentasikan kondisi anak-anak Indonesia secara umum, yang masih sangat tertinggal jauh di belakang, dibanding dengan negaranegara lain di kawasan Asia khususnya.

Pemerintah Kota (Pemkot) Surabaya terus berupaya meningkatkan kualitas literasi demi menumbuhkan minat baca masyarakat Surabaya. Salah satunya dengan menambahkan jumlah Taman Bacaan Masyarakat (TBM).

Oleh karena itu dalam pelaksanaan Pengabdian Masyarakat, kami tertarik pada program melestarikan budaya literasi kepada masyarakat di Dusun Lidah 
Wetan, Kecamatan Lakarsantri, Kota Surabaya, Provinsi Jawa Timur, dimana minat baca masyarakat terutama anak-anak masih rendah, jadi tujuan utama dari program ini adalah untuk membangkitkan budaya literasi dan minat baca anakanak, hal ini direalisakan pada kegiatan antara lain :

Pembuatan Taman Baca yang terdiri dari kegiatan pembuatan rak buku dan renovasi tempat lokasi didirikannya taman baca dimaksudkan agar dapat terciptanya taman baca serta meningkatkan ketertarikan masyarakat terutama generasi muda dalam melestarian budaya literasi. Pengabdian masyarakat di dusun Lidah Wetan juga melakukan sosialisasi untuk mengenalkan taman baca yang telah di dirikan kepada pemuda-pemuda karang taruna dan remaja di sekitarnya agar setidaknya dapat ikut serta dalam menjaga dan merawat taman baca yang sudah didirikan agar tetap ada dan semakin berkembang (besar) kemudian hari.

\section{Metode}

Pelaksanaan program kegiatan tim pengabdian masyarakat ini dilaksanakan dengan pendekatan pemberdayaan masyarakat dan anak-anak usia PAUD melalui PRA (Participatory Rural Appraisal) yang mana pendekatan dan metode yang memungkinkan masyarakat secara bersama-sama menganalisis masalah kehidupan dalam rangka merumuskan perencanaan dan kebijakan secara nyata. (Aslikhah, 2019)

Kegiatan pengabdian masyarakat ini mengambil tema "Melestarikan Budaya Literasi”, dengan lokasi kegiatan pengabdian masyarakat yang bertempat di Dusun Lidah Wetan, Kecamatan Lakarsantri, Kota Surabaya, Provinsi Jawa Timur. Program tersebut tentu tidak terlepas dari visi dan misi pengurus desa setempat. Dengan adanya perpustakan mini yang dibuat oleh tim pengabdian masyarakat Universitas Bhayangkara ini diharapkan dapat meningkatkan semangat dan minat baca masyarakat sekitar. Perpustakaan mini ini menyediakan berbagai macam buku mulai dari buku cerita anak, buku belajar membaca, buku belajar 
menulis, buku belajar menggambar, materi-materi sekolah, sampai dengan buku bernuansa agama dan buku-buku lainnya (resep makanan, cerita fiksi, dll).

Dalam merealisasikan hal tersebut, beberapa sasaran program tim pengabdian masyarakat dengan menerapkan budaya literasi, diantaranya yaitu :

\section{Pembuatan Taman Baca}

Dalam pembuatan taman baca ini tim pengabdian memulai dengan pembuatan rak buku dan renovasi. Membuat rak buku yang merupakan bagian dari taman baca atau perpustakaan mini agar tersedia tempat untuk buku. Tersedianya taman baca sebagai salah satu upaya meningkatkan minat membaca dan melahirkan generasi cinta baca yang cerdas. Renovasi Taman Baca berjalan dengan baik dan sesuai harapan berdirinya Taman Baca yang menarik (indah) dan bisa dimanfaatkan oleh masyarakat setempat

\section{Belajar Bersama}

Belajar bersama dalam program literasi ini adalah dengan tujuan sekaligus memperkenalkan Taman Baca yang sudah di buat untuk masyarakat sekitar. Mendekatkan diri dengan anak-anak dan masyarakat sekitar, membantu anak-anak untuk mengerjakan tugas sekolah ataupun membaca buku-buku serta memberikan tambahan wawasan atau ilmu mengenai pengetahuan umum dan budaya membaca.

\section{Hasil dan Diskusi}

Kegiatan pengabdian masyarakat yang dilaksanakan di dusun Lidah Wetan, dengan tema "Melestarikan Budaya Literasi dengan Pembuatan Perpustakaan Mini/Taman baca" antara lain meliputi: Agenda awal yang dilaksanakan berupa rapat program kerja. Rapat dengan perangkat desa terkait program pengabdian masyarakat yang bertemakan "melestarikan budaya literasi". 
124 | Pendampingan Masyarakat Dusun Lidah Wetan dalam Pelestarian Budaya ...
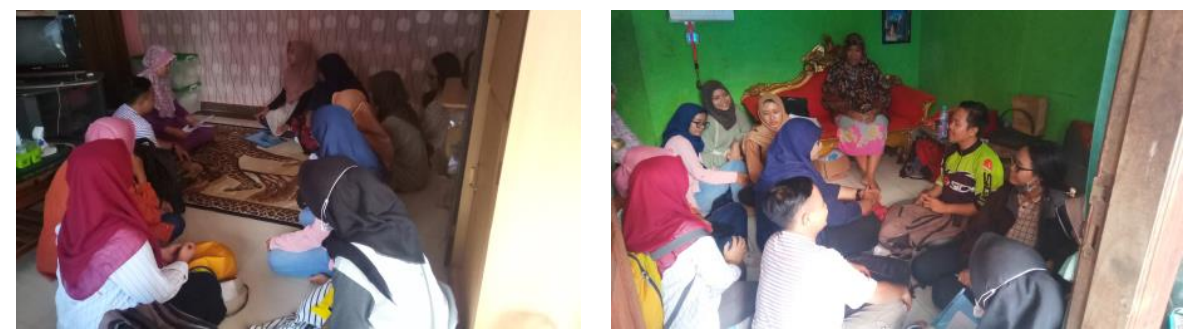

Kegiatan selanjutnya adalah koordinasi dan diskusi yang berhubungan dengan PAUD. Rapat dengan perwakilan bunda PAUD terkait program pengabdian masyarakat yang berhubungan dengan pembelajaran anak-anak paud dan penggunaan lokasi belajar paud. Rapat koordinasi kelompok bersama dengan seluruh anggota kelompok terkait koordinasi program pengabdian masyarakat Tematik yang akan dijalankan. Koordinasi sangat diperlukan agar kegiatan yang akan dilaksanakan berjalan sesuai dengan tujuan yang telah ditetapkan bersama.

Pembukaan yang dihadiri oleh Dosen Pembimbing, Perangkatt desa, Pengurus PAUD kuncup bunga serta peserta pengabdian masyarakat Tematik Universitas Bhayangkara Surabaya.
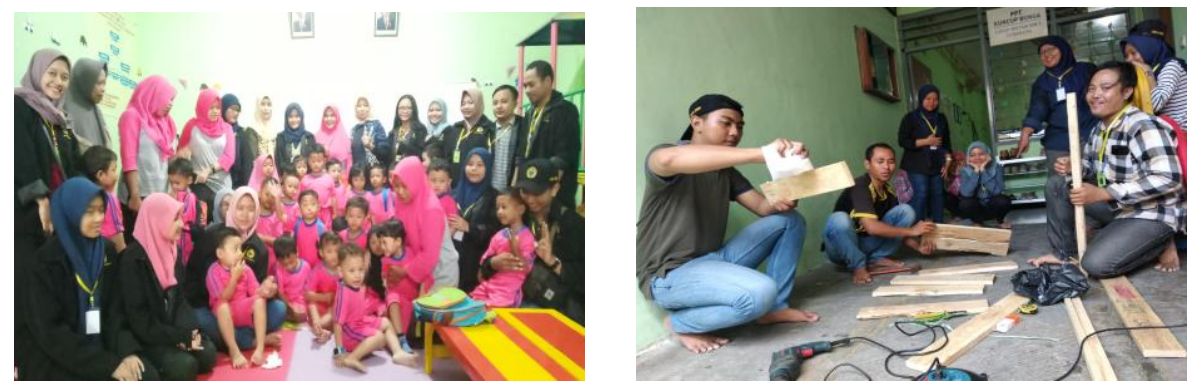

Pembuatan rak buku. Pembuatan rak ini dilakukan step by step dari memotong, mengamplas sampai dengan merakit papan kayu yang sudah dibeli menjadi rak yang bisa digunakan untuk penyimpanan buku-buku. Renovasi taman baca. Renovasi ini dilakukan agar taman baca yang dibuat lebih terlihat menarik dengan penempatan buku-buku yang sudah disiapkan dan beberapa hiasan serta sentuhan pernak-pernik yang telah dibuat sebelumnya. 

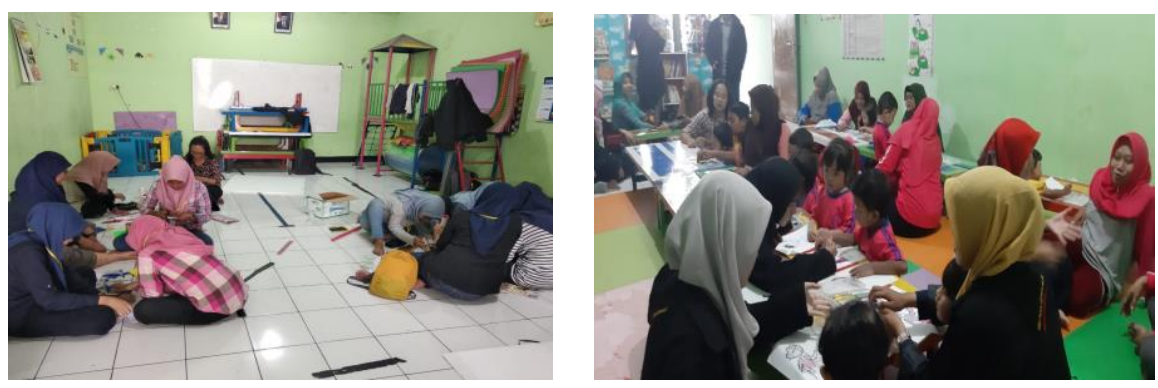

Dalam pengabdian kepada masyarakat kali ini di akhiri dengan kegiatan belajar bersama dengan tujuan mengenalkan taman baca yang sudah dibuat kepada masyarakat sekaligus sharing ilmu dan lebih mendekatkan diri anak pada ilmu pengetahuan dengan diselingi permainan yang menunjang dalam kegiatan tersebut.

\section{Kesimpulan}

Program perpustakan mini yang dibuat oleh tim pengabdian masyarakat Universitas Bhayangkara ini diharapkan dapat meningkatkan semangat dan minat baca masyarakat sekitar. Untuk dapat merealisasikan hal tersebut, disusun beberapa program pengabdian dalam penerapan budaya literasi, diantaranya pembutan Taman Baca, yang terdiri atas Pembuatan rak buku dan Renovasi serta program belajar bersama, dengan tujuan sekaligus memperkenalkan Taman Baca yang sudah di buat kepada masyarakat sekitar. Hasil pengabdian menjelaskan tentang dinamika proses pendampingan yang berkelanjutan meliputi: ragam kegiatan yang dilaksanakan, bentuk-bentuk aksi yang bersifat teknis atau aksi program untuk memecahkan masalah komunitas. Sedangkan diskusi hasil pengabdian meliputi diskusi teoritik yang relevan dengan temuan hasil pendampingan dalam menumbuhkan literasi atau minat baca pada masyarakat.

\section{Ucapan Terima Kasih}

Ucapan terima kasih atas peran serta, kerja sama serta dukungan dari rekanrekan tim pengabdian masyarakat Tematik dari 4 Prodi yang ada di Universitas Bhayangkara Surabaya, antara lain: Prodi Akuntansi : Vita Lisya 1712321020, 
126 | Pendampingan Masyarakat Dusun Lidah Wetan dalam Pelestarian Budaya ...

Yuansa Aryo Satya P 1712321033, Devi Rahayu 1712321048, Amanda Wahyu N 1712321052, Alifah 1712321056, Savira Rachmadani 1712321082. Prodi Ekonomi Pembangunan : Khoirul Anwar 1712211016. Prodi Ilmu Komunikasi : Intan Permatasari 1713211011, M. Ihsa Nuddin 1713211019. Prodi Administrasi Publik : Mulyani 1713111063, Diana Elisa P 1713111065, Emilia Pamungkas S 1713111067, Afiva Nutvi 1713111093, Almira Rukhma K 1713111098

\section{Daftar Pustaka}

Arum Nisma Wulanjani, \& Candradewi Wahyu Anggraeni. (2019). Meningkatkan Minat Membaca melalui Gerakan Literasi Membaca bagi Siswa Sekolah Dasar. Proceeding of Biology Education, 3(1), 26-31.

Aslikhah. (2019). Aslikhah | 61. Jurnal Soeropati: Jurnal Pengabdian Kepada Masyarakat, 2(November).

Khoiruddin, M. A., Taulabi, I., \& Imron, A. (2016). Menumbuhkan Minat Baca Sejak Dini di Taman Baca Masyarakat. Journal An-Nafs: Kajian Penelitian Psikologi, 1(2), 291-319.

Teguh, M. (2013). GERAKAN LITERASI SEKOLAH DASAR Mulyo Teguh. Pendidikan, 2(1), 18-26. 